\title{
Urgency of Career Understanding of High School Students in Making Career Decisions
}

\author{
Risnasari Z* \\ Guidance and Counseling Department \\ Universitas Negeri Yogyakarta \\ Yogyakarta, Indonesia \\ risnasariz.2018@student.uny.ac.id*
}

\author{
Agus Basuki \\ Guidance and Counseling Department \\ Universitas Negeri Yogyakarta \\ Yogyakarta, Indonesia \\ agus_basuki@uny.ac.id
}

\begin{abstract}
Career is important in one's life. A good career must be prepared since students have been able to understand themselves and understand the various types of careers that exist. That way students easily make career decisions that they will choose later. High school students are considered to have to prepare their careers well because a person's career can determine the welfare of the life to come. The purpose of this literature study is to explain the urgency of career understanding that high school students must have in making career decisions.
\end{abstract}

Keywords - career understanding, career decisions

\section{INTRODUCTION}

In this modern era, the development of education is increasingly advanced both formal and non-formal education. Formal education is part of helping students to achieve career development. In the field of career guidance and counseling career guidance is one type of service from the guidance and counseling program. Career is a very important thing for someone's life according to career influences human life as a whole in deciding the most important career thing in every human life. To be able to decide a career correctly requires an understanding of careers.

Career understanding can be obtained from the role of the Guidance and Counseling teacher in schools in providing information services and career guidance [1]. Suggests the role of guidance and counseling teachers in schools that is helping students to develop and make informed decisions in career choices [2]. Career decisions are chosen by each student from the time they enter adolescence, adolescents are considered to have been able to understand themselves to be able to make career decisions, this is reinforced by opinions Santrock who said that during adolescence, adolescents develop optimally in the cognitive aspects of adolescence into the formal thinking process [3]. It can be said that late teens have entered the stage of thinking intellectually or thinking logically to make a career plan that has been well understood, therefore the need for good career understanding for high school students to be able to make career decisions appropriately. So that understanding can be said as a person's ability to understand information by explaining their sentences such as the ability to explain, interpret, conclude and plan.

Who explained that teachers of guidance and counseling in schools must carry out career guidance to the maximum and effectively to prevent students dropping out of school which results in poverty, increased unemployment, interdependent of each other's lives and low quality of life amid social and social life current development [2]. Career understanding is an important aspect of career guidance and counseling service programs, which is meant career guidance and counseling that is an understanding of development, exploration, aspirations and rational and realistic career decision making by the potential and career opportunities that exist [4]. Efforts that can be given to students are by providing career understanding so that students can understand as a whole what is a true career. Career understanding can be concluded that a student's mastery of the world of careers is characterized by a deep introduction to various career information available.

Creed, Wong Hood argues that career decisions are complex endeavors that require information about themselves and future careers [5]. Career decision is a process of choice to choose an education and occupation which is covered by opportunities to be taken then interests, personality types, feelings of obstacles and vocational identities owned [6].

Dewa Ketut Sukardi states career decision making is a process in which a person makes a selection of various choices related to plans [7]. According to Gati, Krausz and Osipow career decision making is a process of individuals realizing a need in making career decisions, being able to realize, being able to make decisions correctly and by the individual's life goals [8].

The career decision-making process is a career decisionmaking process that is a process of determining career choices from several choices based on self-understanding and career understanding [9]. Santrock explains that in making career decisions many teenagers experience changes in making decisions due to lack of exploring career choices themselves and too little to receive guidance from school counselors [3]. 
Career decision making is a process that determines the future of a person to have independence regarding job choices by interests and abilities [10]. Brown explains decision making not only involves the process of making career decisions but commitment in carrying out choices, decision making includes a person's activities in carrying out the commitments that must be carried out to support the goals of the specified career choice [11].

Based on the definition of career decision making above, it can be concluded if career decision making is a process carried out by individuals in choosing education and work which is covered by personal aspects (interests, personality types, vocational identity, feelings of obstacles) and aspects of information related to the choices that will be was taken.

The purpose of this literature study is to show the importance of career understanding that students must have to be able to make career decisions so that students make career decisions that are by their abilities and career knowledge. Career understanding can be seen from the independence of students in deciding careers such as confidence in making decisions, understanding about selfinterest, being able to understand the various career choices that exist.

\section{METHODS}

The method used is a literacy study with research subjects of high school students. The type of data used is secondary data. The data collection method is a literature study. The method to be used is the literature study. The data obtained are compiled, analyzed, and concluded to obtain conclusions regarding the study of literature.

\section{RESULT AND DISCUSSION}

Result

The results of the literature study that has been carried out is the importance of understanding the career of high school students very influential on student career decision making. Students who have a good career understanding will easily make career decisions. Career understanding can be obtained with a lot of career information obtained from the guidance and counseling teacher at school. Career decisions can be chosen by high school students because the age of high school students can already think intellectually and think logically.

\section{Discussion}

Career decision making is a complex process, based on the normative theory of decision making, the best career decision is to assist individuals in making decisions. Decision making is a process that begins through the selection of alternative comparisons and evaluations available [8] Students make a career decision based on career understanding that has been understood so that students develop a process of understanding critical thinking.

Factors that influence adolescent career decision making including peers, geographical location, educational institutions, political conditions, family, historical trends, media and globalization [12]. The past condition also influenced the career selection process such as the labor market, workplace, social status, economy, and a community group.

Describe several issues relating to adolescents who experience problems with the type of education related to the type of work in the future, career planning, decision making about travel for the future and the latter must be had [13].

Students' efforts in making desired career decisions sometimes face obstacles in the process. Barriers such as several factors that can hinder students' efforts to achieve the expected goals such as the environment that comes from oneself or themselves.

Based on these explanations in career decision making several factors can influence students in making decisions. Students who already understand careers well will consider several factors that they usually face in being able to make career decisions appropriately. The implementation of career guidance services can be carried out well if supported by counselors or teachers of guidance and counseling in schools by creating programs related to the provision of career information services that will provide a career understanding to students. For this reason, there needs to be a role of guidance and counseling teacher in providing career guidance related to career understanding to make career decisions precisely in accordance with the state of students themselves. Career guidance is one type of guidance that seeks to help students in solving career problems to be able to get the best self-adjustment in the hope that the service is provided to students so that students are able to gain an understanding of themselves and the world of work that is finally able to determine career choices.

\section{CONCLUSION}

Based on the study of literature above, it can be concluded that the importance of students understanding careers so they can decide career well. Understanding student careers is also a demand for teacher guidance and career counseling that should provide information services related to career, position, vocational and other information. That way students can look for various sources of information also about self-understanding related to existing careers. The right career decision can have an impact on the welfare of students' lives such as independence of students, reducing poverty, reducing unemployment, and dependence on one another.

\section{ACKNOWLEDGMENT}

The author thanks the parties involved in writing this article. Hopefully, this article writing can be useful for readers in scientific development needed. The author also expresses his gratitude for the Postgraduate program of Yogyakarta State University's Guidance and Counseling Study Program.

\section{REFERENCES}

[1] Rio Hermawan\&Muh Farozin "The role of career exploration in career decision participants". The International Journal of Counseling and Education. Vol3-4 2018.

[2] Egemen Hanimoglu "The Perceptions of Students about the Role of School Counselors on Career Selection" European Journal of Educational Research. Vol 7-4 2018. 
[3] Santrock, John W. "Psikologi Pendidikan". Edisi Kedua. Jakarta: Kencana 2010

[4] Mendikbud "Peraturan Kementrian Pendidikan dan Kebudayaan" Tentang Bimbingan dan Konseling pada Pendidikan Dasar dan Pendidikan Menengah No 111 tahun 2014.

[5] Creed, P. A., Wong, O. Y., \& Hood, "MCareer decision-making, career barriers and occupational aspirations in chinese adolescents" International Journal for Educational and Vocational Guidance, 9(3),189-203 2009

[6] Lee, I. H., Rojewski, J. W., \& Hill, R. B. "Classifying korean adolescents' career preparedness" International Journal.

[7] Dewa Ketut Sukardi "Psikologi Pemilihan Karier" Jakarta: Rineka Cipta1993.

[8] Gati, I., Krausz, M., \& Osipow, S. H. "A taxonomy of difficulties in career decision making" Journal of Counseling Psychology, 43(4), 510-526 1996
[9] Hartono. "Bimbingan Karier Berbantuan Komputer Untuk Siswa SMA" Surabaya: UNIPA University Press 2010.

10] Edris Zamroni "Urgensi Career Decision making skill dalam penentuan arah peminatan peserta didik". Jurnal Konseling Gusjigang Vol2(2) 2016.

[11]Brown, D "Career Choice And Development Fourth Edition" San Fransisco: Jossey Bass Company 2002.

[12]Patton, W., \& McMahon, M. Career Development Programs: "Preparation for lifelong career decision making". (A. C. for E. R Ltd, Ed.). Melbourne 2001.

[13] Leksana, D.M., Wibowo, M.E., Tadjri, I. "Pengembangan Modul Bimbingan Karir Berbasis Multimedia Interaktif Untuk Meningkatkan Kematangan Karir Siswa”.Jurnal Online Universitas Negeri Surabaya, (online)

2013 